\title{
PATERNIDADES E A IDENTIDADE DO SUJEITO CONSTITUCIONAL NO BRASIL: UM ESTUDO A PARTIR DO DIREITO FUNDAMENTAL À LICENÇA-PATERNIDADE ${ }^{1}$
}

\author{
PATERNITIES AND THE IDENTITY OF THE CONSTITUTIONAL \\ SUBJECT IN BRAZIL: A STUDY FROM THE FUNDAMENTAL RIGHT TO \\ PATERNITY LEAVE
}

\author{
Marcelo Andrade Cattoni de Oliveira \\ Universidade Federal de Minas Gerais - UFMG - (Belo Horizonte, MG, Brasil) \\ Stanley Souza Marques \\ Universidade Federal de Minas Gerais - UFMG - (Belo Horizonte, MG, Brasil)
}

Recebimento: 10 maio 2017

Aceitação: 18 dez. 2017

\begin{abstract}
Como citar este artigo / How to cite this article (informe a data atual de acesso / inform the current date of access):
CATTONI DE OLIVEIRA, Marcelo Andrade; MARQUES, Stanley Souza. Paternidades e a identidade do sujeito constitucional no Brasil: um estudo a partir do direito fundamental à licença-paternidade. Revista da Faculdade de Direito UFPR, Curitiba, PR, Brasil, v. 63, n. 2, p. 9-38, ago. 2018. ISSN 2236-7284. Disponível em: <https://revistas.ufpr.br/direito/article/view/52320>. Acesso $\quad$ em: $30 \quad$ ago. $2018 . \quad$ DOI:
\end{abstract} http://dx.doi.org/10.5380/rfdufpr.v63i2.52320.

\section{RESUMO}

Num diálogo crítico com autores como Michel Rosenfeld, o artigo reconstrói a constitucionalização da licença-paternidade como um corte na paternidade tradicional ou pré-constitucional, aquela variante da paternidade absorvida pelo encargo do provimento material. A Constituição de 1988, ao reconhecer a licença-paternidade como direito fundamental, movimento inédito na história do constitucionalismo brasileiro, explicita o caráter vazio e transbordante de categorias como paternidade e maternidade, masculinidade e feminilidade; caráter também explorado pelos embates constitucionais e legislativos mais recentes sobre a regulamentação da licença-paternidade. $\mathrm{O}$ artigo reconstrói, no marco da teoria da identidade do sujeito constitucional, a disputa pelo significado das categorias aludidas, acirrada já no curso do processo constituinte de 1987-88. Com a reconstrução de fragmentos dessa disputa, aberta e mediada por uma Constituição que tensiona concepções tradicionais da paternidade (e, numa perspectiva relacional, também da maternidade), o artigo contribui não só com as reflexões sobre os potenciais emancipatórios imanentes à constitucionalização da licença-paternidade, mas também apresenta elementos para um debate sobre a identidade constitucional que nós, como sociedade política, construímos nas últimas três décadas.

\footnotetext{
${ }^{1}$ Este artigo é fruto da pesquisa desenvolvida durante o Mestrado em Direito, no Programa de Pós-Graduação em Direito da Faculdade de Direito da UFMG, e retoma em parte o texto da dissertação cujo tema foi “A Identidade do Sujeito Constitucional e o Direito Fundamental à Licença-paternidade”. Agradecemos à Professora Maria Fernanda Salcedo Repolês, da Faculdade de Direito da UFMG, e ao Professor Marco Aurélio Máximo Prado, da Psicologia da UFMG, pelas observações e sugestões que também serviram de base para esta publicação. Sobre desdobramentos dessa pesquisa, ver também MARQUES, 2014; MARQUES, 2015; MARQUES, 2016b; CATTONI DE OLIVEIRA; MARQUES, 2017.
} 


\title{
PALAVRAS-CHAVE
}

Identidade do sujeito constitucional. Direito fundamental à licença-paternidade. Paternidades. Maternidades. Masculinidades.

\begin{abstract}
In a critical dialogue with authors such as Michel Rosenfeld, the article reconstructs the constitutionalization of paternity leave as a cut in traditional or pre-constitutional parenthood, that variant of paternity absorbed by the burden of material provision. The Constitution of 1988, recognizing paternity leave as a fundamental right, an unprecedented movement in the history of Brazilian constitutionalism, makes explicit the empty and overflowing character of categories such as paternity and maternity, masculinity and femininity; a character also explored by the most recent constitutional and legislative clashes over the paternity leave regulation. The article reconstructs, within the framework of the theory of the identity of the constitutional subject, the dispute over the meaning of the aforementioned categories, fierce already in the course of the constituent process of 1987-88. With the reconstruction of fragments of this dispute, open and mediated by a Constitution that destabilize traditional concepts of paternity (and, from a relational perspective, also of motherhood), the article contributes not only to the reflections on the emancipatory potentials immanent to the constitutionalization of the paternity leave, but also presents elements for a debate on the constitutional identity that we, as a political society, have built up over the last three decades.
\end{abstract}

\section{KEYWORDS}

Identity of the constitutional subject. Fundamental right to fatherhood leave. Fatherhood. Motherhood. Masculinities.

\begin{abstract}
Passo tempo demais em casa com Colette depois que ela se recuperou. Apesar da sua grande gentileza, sinto que minha solicitude corre o risco de importuná-la. Quando se viveu de tal maneira para os outros, é um pouco difícil começar a viver para si. Não cair nas armadilhas da dedicação: sei muito bem que as palavras dar e receber são intercambiáveis e como eu tinha necessidade da necessidade que minhas filhas tinham de mim. Nesse sentido nunca blefei. "Você é maravilhosa”, dizia-me Maurice. Ele me dizia isso frequentemente, a qualquer pretexto. "Porque, para você, dar prazer aos outros é antes dar prazer a você mesma.” Eu ria: "É verdade, é uma forma de egoísmo.” Aquela ternura em seus olhos: “A mais deliciosa que existe.”
\end{abstract}

(BEAUVOIR, 2015, p. 97-98)

\section{CONSIDERAÇÕES INTRODUTÓRIAS}

Tomado como ponto de partida o "projeto constituinte de sociedade, subjacente à Constituição de 1988”, e seu compromisso com “a construção de uma sociedade fraterna [...], com o pluralismo social e cultural, com a democracia e com a justiça social, com o Estado Democrático de Direito e com os direitos fundamentais” (CATTONI DE OLIVEIRA, 2006, p. 47-48), uma pergunta atravessa todo o presente ensaio: em que medida nós, como sociedade política, desdobramos esse “projeto constituinte de sociedade”? Ou, dito diferentemente, como temos construído a identidade constitucional? É na tentativa de contribuir, ainda que de modo provisório e aberto, para uma reflexão 
sobre essa pergunta, que nos voltamos para a constitucionalização do direito fundamental à licençapaternidade e para as tentativas mais recentes de regulamentação desse direito. Assumimos que a reconstrução de fragmentos dos embates constitucionais e legislativos sobre a licença-paternidade pode ajudar a tatear um diagnóstico possível, uma narrativa suficientemente consistente e complexa da identidade constitucional que nós construímos. É precisamente daqui, do confronto de discursos constitucionais controversos, que se projetam imagens da identidade constitucional.

Focalizamos as discussões sobre a licença-paternidade, acirradas já no curso do processo constituinte de 1987-88, porque são particularmente ilustrativas (i) da disputa entre concepções concorrentes da maternidade e da paternidade, da identidade e da diferença; (ii) do caráter evasivo, aberto, fluido, tenso e dinâmico do sujeito e da identidade constitucionais; (iii) dos potenciais emancipatórios e dos limites da Constituição e de seu complexo sistema de direitos²; (iv) e das ameaças recorrentes com as quais aquele sujeito e aquela identidade se defrontam sem poder jamais exorcizá-las de uma vez por todas.

Num diálogo com autores como Rosenfeld (2003a, 2010, 2012), de quem tomamos de empréstimo a construção teórica da identidade do sujeito constitucional (cf. também CATTONI DE OLIVEIRA, 2006, 2011, 2016a, 2016b, 2016c; CARVALHO NETTO, 2002, 2003a, 2003b; SALCEDO REPOLÊS, 2004), procuramos reconstruir a constitucionalização do direito fundamental à licença-paternidade como um corte na paternidade tradicional ou pré-constitucional. É dizer, o reconhecimento da licença-paternidade como direito fundamental tensiona concepções da paternidade que correlacionam o "ser pai” com o "ser provedor” e, em alguma medida, subverte modelos tradicionais de maternidade. A Constituição, de caráter contratradicional, ao consagrar o direito fundamental à licença-paternidade, desenraíza a paternidade (e, numa perspectiva relacional, também a maternidade) de suas matrizes históricas. Os constituintes, quando reconstroem concepções tradicionais da paternidade e da maternidade, resgatam e explicitam sua historicidade, não sem tensões. Aqui, paternidades e maternidades emergem como problema com o qual a sociedade terá de lidar, embora jamais definitivamente.

\footnotetext{
${ }^{2}$ Limites que também se desdobram do fato de que “o Direito não é capaz por si só de transformar a realidade ou de transformar o mundo [...] [.] Que no máximo, no máximo, a Constituição pode promover mudanças na medida em que essa Constituição constitua algo. Que ela seja o centro de mobilização ou de integração política de uma sociedade, no sentido do desenvolvimento de um patriotismo constitucional, [...] no sentido de Jürgen Habermas, que diz respeito à construção de uma cultura ético-política pluralista com base na Constituição” (CATTONI DE OLIVEIRA, 2016c, p. 16).
} 


\section{O CENÁRIO DA ARGUMENTAÇÃO}

“Por que abandonou a criança?” Foi com essa pergunta que, num certo dia de outubro de 2015, repórteres e curiosos receberam Sandra Maria dos Santos, detida pela polícia. Presa por “abandonar” uma recém-nascida ao pé de uma árvore no bairro nobre de Higienópolis, São Paulo, onde trabalhava como empregada doméstica, Sandra, abatida e assustada, declarou à imprensa ter enjeitado a criança “por desespero”. Mãe de outros dois filhos, escondeu a gravidez ao longo dos nove meses, pariu sozinha no banheiro anexado ao seu quarto de empregada, cortou o cordão umbilical, limpou, vestiu, amamentou e envolveu a filha numa sacola. Não em qualquer sacola, mas numa que levava o nome de um refinado restaurante parisiense. Por quase uma hora perambulou pelas ruas próximas à árvore onde finalmente deixou a bebê. Afastou-se, mas não muito, e aguardou até ver sua filha ser encontrada por Francisco de Assis Marinho, zelador, tornado herói (BRUM, 2015). Nesta trama, historicamente corriqueira, vociferam os indignados com a irresponsabilidade, senão monstruosidade, de Sandra. Sobram adjetivos que a desqualificam como mulher; uma "safada”, para um segurança particular que residia na mesma rua de Sandra. Já o pai da criança, Edmilson, com quem Sandra esteve por uma noite, passa quase despercebido, quando não ocultado, pelo estigma que agora pesa sobre a mãe desnaturada.

Sete meses depois, no Rio de Janeiro, uma funcionária do BarraShopping interpelava Diego Braga da Silva: “o senhor vai ter que se retirar”. Na ocasião, ele e sua mulher, Agatha Cristina Barbosa, cuidavam dos filhos, um casal de gêmeos, no fraldário do estabelecimento. O fato de uma outra mãe ter adentrado o ambiente para amamentar o seu filho teria motivado a expulsão de Diego do Espaço Família. O episódio, responsável pelo fim antecipado do passeio familiar, desencadeou um desabafo de Agatha numa rede social, seguido de uma nota do shopping que lamentava o ocorrido e informava a adoção de novas posturas pelos funcionários (NASCIMENTO, 2016).

Os episódios protagonizados por Sandra, Diego e Agatha evocam concepções da maternidade e da paternidade tornadas hegemônicas num período historicamente recente. Precisamente porque são concepções historicamente datadas, interessa-nos, num primeiro momento, localizar o ponto de partida de sua formulação, identificar o seu contexto inicial de elaboração e os objetivos que orientaram a atribuição estratégica de certos significados à maternidade e à paternidade. Interessa-nos também reconstruir as tensões imanentes ao processo de sedimentação de alguns entendimentos e de algumas expectativas projetadas sobre a maternidade e sobre a paternidade na modernidade. 
Interpelados pelas pretensões acima aludidas, recuamos ao contexto de emergência de certos movimentos socio-históricos que, a um só tempo, convertem a criança em figura prestigiada no interior de um arranjo familiar específico, o modelo nuclear e conjugal, e sacralizam o instinto ou o amor materno, então reconstruído como sentimento predeterminado, universal e necessário. Movimentos que remontam ao Brasil dos séculos XIX e XX, mais especificamente, a projetos audaciosos de implementação da ordem burguesa, de modernização e de higienização, cujo sucesso também dependia da reorganização radical dos arranjos familiares, da fabricação de novas concepções da maternidade e da paternidade, agora orientadas em torno da criança de elite, por muito tempo conservada no anonimato (COSTA, 2004; RAGO, 2014; MARQUES, 2016a).

Administradores públicos, médicos-higienistas, moralistas, intelectuais e articulistas da imprensa foram algumas das personagens que, naquela altura, promoveram uma enérgica investida contra quem desafiava, ou julgavam estorvar, o triunfo do projeto modernizador nacionalista. Entre os seus alvos prediletos, as mulheres, certamente, sobretudo aquelas que não se curvavam docilmente à feminilidade e à maternidade ali forjadas, é dizer, aquelas que desafiavam a expectativa despontante da servidão doméstica feminina. Aos poucos, a associação ali inicialmente costurada entre feminilidade, maternidade, devotamento, cuidado e domesticidade torna-se particularmente familiar.

Ali já se esboçam alguns dos elementos do “mito [moderno] da 'Mãe Perfeita'”, aquele que, segundo Forna (1999, p. 11), enquadra a mulher como "a melhor, e a única capaz de cuidar corretamente dos filhos, [...] que [...] exigem sua presença contínua e exclusiva”. Ou, como prefere Hays (1998, p. X), ali se costuram os primeiros fios da "ideologia da maternidade intensificada", aquela "que aconselha as mães a despenderem uma enorme quantidade de tempo, energia e dinheiro na criação de seus filhos”. O “mito da mãe perfeita” de que fala Forna ou a "ideologia da maternidade intensificada” trabalhada por Hays desdobram-se, em grande medida, de discursos científicos, filosóficos e populares insistentemente repetidos, já no século XVIII na Europa e um século mais tarde no Brasil. Dirigidos (não só) às mulheres, promoviam o protagonismo delas no espaço doméstico, arena desprestigiada, invisível e feminina por excelência (BADINTER, 1985). Somente na instância doméstica e se decididas e silenciosamente observadas as sacrificantes prescrições da maternidade, poderiam as mulheres alcançar algum reconhecimento social e ocupar um lugar de poder na dinâmica familiar. À identidade delas, colava-se, não acidentalmente, a maternidade, a ponto de se confundirem. Não acidentalmente porque a maternidade só "está no centro das definições culturais e históricas do feminino” porque traduz, nas palavras de Martins (2005, p. 1), “o papel que se espera das mulheres da sociedade”. 
Daí por que, embora diferentes períodos históricos tenham conhecido distintos modelos hegemônicos de maternidade, superficialmente reconstruídos e reapropriados conforme os cenários, as personagens, os interesses e as relações de poder em jogo, todos eles compartilharam (e ainda compartilham) um núcleo duro que poderia ser resumido na ideia de uma maternidade absorvente. Todos os modelos de boa maternidade tornados hegemônicos na modernidade creditam às mães, e apenas a elas, um pesado investimento físico, afetivo, cognitivo e monetário. Investimento que pressupõe a centralidade da criança, cujas necessidades demandam satisfação prioritária, uma espécie de "império do bebê", nas palavras de Badinter (2011). Essa premissa desdobra-se em duas ideiaschave; uma, a de que a criança, porque "naturalmente” inocente, pura e dependente, requer atenção devotada, e outra, a de que o cuidado psicológico, social e intelectual da prole se confunde com o cuidado materno, expressão de um “natural” amor maternal ${ }^{3}$, do qual nenhuma mulher escaparia, salvo as deficientes, egoístas, incompletas, todas elas (ainda) duramente censuradas (MARQUES, 2016a).

Embora num cenário radicalmente diferente daquele onde se costurou os primórdios da maternidade devotada; ainda que a maternidade não mais absorva a identidade feminina; a despeito do impacto dos feminismos e da diversificação das expectativas creditadas às mulheres e da heterogeneidade de suas aspirações e experiências; apesar do ingresso vertiginoso delas no mercado de trabalho e das redefinições recentes das conjugalidades, o mito da maternidade ainda ocupa um lugar intocado, pretensamente universalizado, sacralizado, radicalmente mais absorvente do que a paternidade (AGUAYO; BARKER; KIMELMAN, 2016; NASCIMENTO, 2016; ARAÚJO; SCALON, 2005; LEVTOV et al., 2015), impondo falsa homogeneidade a uma realidade fluida e contraditória e, nesse sentido, (ainda) essencialista, violadora da historicidade e encobridora das tensões das experiências maternais (e paternais).

Violadora da historicidade e encobridora das tensões das experiências de mulheres e de homens porque o mito da maternidade encobre a dimensão das disputas agressivamente travadas nos últimos séculos em torno dos controversos significados da maternidade e da paternidade. Embates

\footnotetext{
${ }^{3}$ Paradoxalmente, parece ter sido fundamental que muitos homens lembrassem às mulheres de seu instinto maternal e muitos o fizeram (e ainda o fazem) invocando ameaças travestidas de ciência. Em outras palavras, uma tensão perpassou (e ainda perpassa) muitos dos discursos relativos à maternidade: ela transcende a dimensão biológica na medida em que o instinto maternal, expressão máxima da essência feminina, surge insuficiente para o exercício da boa maternagem. A boa mãe, advertem, sobretudo, médicos(as), psicólogos(as), pedagogos(as) e educadores(as), é a mãe instruída. Parece suficiente recordar a popularização dos manuais e das revistas sobre a boa maternidade e as acusações que ainda pesam sobre as mães (e apenas sobre elas) pelo fraco desempenho escolar, delinquência, autismo ou mesmo psicopatia dos(as) filhos(as). Para todos estes infortúnios, e muitos outros, a explicação estaria no comportamento de muitas mães, que, a despeito de todas as informações que lhes foram ministradas por especialistas, não foram (suficientemente) boas mães por negligência ou opção.
} 
que, em última instância, procuravam (e ainda procuram) precisar os contornos de modelos de boa maternidade, comumente arredios ao cotidiano da maioria das mulheres. Longe de revelar meras expressões biológicas, experiências universais, homogêneas ou modelos trans-históricos, a gravidez, o parto e o cuidado com a prole são diversamente interpretados, vivenciados, permanentemente e mais ou menos contestados, sujeitos a deslizamentos históricos e a resistências afiadas a deslocamentos (já) em curso. Enfim, a maternidade (e a paternidade) significa(m) coisas diferentes em diferentes épocas para diferentes pessoas.

A veneração renovada do mito da maternidade explica em parte a divisão sexual do trabalho (e do tempo) ${ }^{4}$, dramaticamente desvantajosa para as mulheres ${ }^{5}$. E quanto a este aspecto, nada de novo na literatura científica: em média, as mulheres se dedicam pelo menos duas vezes e meia a mais do que os homens às atividades domésticas e de prestação de cuidados não remuneradas. Estes, porque desobrigados dos afazeres domésticos e de cuidado, trabalham mais horas no emprego remunerado do que aquelas. Situação diferente se contemplados conjuntamente o trabalho não remunerado e o trabalho remunerado: neste caso, elas trabalham mais do que eles. E muito embora esteja em curso um movimento de atenuação das disparidades entre mulheres e homens, ele decorre principalmente da redução no tempo gasto por elas e menos do comprometimento deles com o trabalho doméstico (OIT, 2016).

Embora a reconstrução da maternidade mitificada ajude a explicar tempos e tipos de envolvimento marcadamente distintos de homens e de mulheres na criação de crianças e no trabalho doméstico, ela, porém, não esgota o diagnóstico. A persistência do mito da maternidade, que ainda pesa sobre as mulheres, e a distância dos homens da trama doméstica são também explicadas por variantes hegemônicas da masculinidade, ainda orientadas pelo repúdio de uma feminilidade forjada. Delas, desdobram-se concepções da paternidade capturadas pela responsabilidade, pelo sustento

\footnotetext{
${ }^{4}$ Por divisão sexual do trabalho entende-se a conjugação de “dois princípios organizadores: o princípio de separação (existem trabalhos de homens e trabalhos de mulheres [os primeiros ligados à produção e os segundos à reprodução]) e o princípio hierárquico (um trabalho de homem 'vale' mais que um trabalho de mulher [mesmo quando ambos estão à frente do trabalho produtivo]). Esses princípios são válidos para todas as sociedades conhecidas, no tempo e no espaço [embora numa miríade considerável de encarnações]. Podem ser aplicados mediante um processo específico de legitimação, a ideologia naturalista. Esta rebaixa o gênero ao sexo biológico, reduz as práticas sociais a 'papéis sociais' sexuados que remetem ao destino natural da espécie” (HIRATA; KERGOAT, 2007, p. 599). Em outro texto, Hirata e Kergoat (2003, p. 114) afirmam que “em nossas sociedades salariais, a divisão do trabalho entre os sexos é o que está em jogo nas relações sociais de sexo. [...] [S] uprima-se a imputação do trabalho doméstico ao grupo social das mulheres e são as relações sociais que desmoronam, junto com as relações de força, a dominação, a violência real ou simbólica, o antagonismo que elas carregam. A divisão sexual do trabalho está no âmago do poder que os homens exercem sobre as mulheres".

${ }^{5}$ Elas, por sua vez, experienciam esta desvantagem de forma acentuadamente heterogênea, conforme recortes (não só) de classe e raça (ARAÚJO; SCALON, 2005; OIT, 2016).
} 
financeiro, pela autoridade, mas não pelo cuidado físico diário da prole. Daí por que dizer que a redivisão democrática dos encargos domésticos e de cuidado das crianças também esbarra em noções naturalizadas da masculinidade e da paternidade (CATTONI DE OLIVEIRA; MARQUES, 2017), noções que negam aos homens a condição de sujeitos mais ou menos engajados ao longo do tempo em práticas contraditórias de gênero (CONNELL, 1995, 2005) ${ }^{6}$. Enfim, noções que negam às identidades a condição de projetos de longa duração, ora harmoniosos e satisfatórios, ora acentuadamente conflitivos e angustiantes, porque associados com o poder generificado.

Subscrevendo o conceito de masculinidade hegemônica, escreve Kimmel (1997, p. 50-51, tradução nossa) que “[u]ma definição de macheza (hombría) segue sendo a norma em relação à qual se medem e se avaliam outras formas de virilidade”. Uma espécie, diz ele, de "prova implacável”7 ou, adaptando sua expressão, um tipo de processo implacável, articulado, sobretudo, pela negação da feminilidade $^{8}$ e cujo desdobrar desejavelmente encontra a figura do "homem de verdade", necessariamente, em algum momento, pai, numa relação monogâmica heterossexual (CATTONI DE OLIVEIRA; MARQUES, 2017).

A masculinidade como "prova implacável” de que falam autoras(es) como Badinter (1993), Kimmel (1997) e Gilmore (1994) remete a um escrutínio permanente do desempenho dos homens, aspirantes às credenciais da masculinidade hegemônica e às suas respectivas vantagens simbólicas, sociais, culturais e materiais, aquilo que Connell (2005) chama de “dividendos patriarcais”: seus pares, sejam eles pais, amigos ou colegas de trabalho, revalidam ou não triunfos pessoais no curso do longo e difícil processo de definição, aquisição e manutenção de masculinidades. O tornar-se pai, mas não qualquer pai, o pai autoridade, o pai herói, o pai provedor integra, enquanto elemento-chave, este

\footnotetext{
${ }^{6}$ Acompanhamos Connell (1995, p. 188), para quem a masculinidade emerge como um processo "de configuração de prática em torno da posição dos homens na estrutura das relações de gênero”. Resumidamente, a ideia de uma "configuração de prática" desloca a ênfase daquilo que é esperado para aquilo que de fato é feito (criativa e não mecanicamente) pelos sujeitos, ao passo que "prática" sugere racionalidade e significado histórico para a ação. Já a referência à "posição dos homens" ressalta que falar de masculinidade significa falar de relações sociais e de corpos, afinal, "[o] gênero é, nos mais amplos termos, a forma pela qual as capacidades reprodutivas e as diferenças sexuais dos corpos humanos são trazidas para a prática social e tornadas parte do processo histórico” (1995, p. 189). "[E]strutura de relações de gênero", por seu turno, envolve uma estrutura complexa integrada, entre outros, pela economia, pelo Estado, pela família, pela escola, pelo mercado de trabalho e pela sexualidade. E parte dessa complexidade é explicada, a um só tempo, (i) pela reconstrução de distintas masculinidades no interior de um mesmo contexto, sem que elas sejam vistas como "formas de vida alternativas, ou seja, uma questão de seleção por um consumidor" (2005, p. 116, tradução nossa), e (ii) pelo caráter contraditório assumido por qualquer versão da masculinidade (1995, p. 189).

${ }^{7}$ Semelhantemente, em trabalho sobre a plasticidade transcultural das masculinidades, David Gilmore (1994) fala da masculinidade como competência e da "virilidade 'sob pressão"', que remete à ideia de virilidade à prova, corrente nas sociedades por ele investigadas. Aspecto também identificado por Badinter (1993, p. 4) quando ela aponta a interpelação que recorrentemente desafia garotos e adultos: "[p]rove que você é homem”.

${ }^{8}$ Mais especificamente, "[s]er homem significa não ser feminino; não ser homossexual; não ser dócil, dependente ou submisso; não ser efeminado na aparência física ou nos gestos; não ter relações sexuais nem relações muito íntimas com outros homens; não ser impotente com as mulheres" (BADINTER, 1993, p. 117).
} 
processo de avaliação e de eventual premiação. Ou, ainda, como ressalta Badinter (1993, p. 4), “[a] virilidade não é dada de saída. Deve ser construída, digamos ‘fabricada’. O homem é, portanto, uma espécie de artefato e, como tal, corre sempre o risco de apresentar defeito”. Mais ainda, “[a] garantia do empreendimento é tão baixa que o sucesso merece ser exaltado”. Aqui se insinua uma definição orientada “mais pelo que não se é, do que pelo que se é”, e quanto a este aspecto em particular, “sejam quais forem as variações de raça, classe, idade, etnia, ou orientação sexual, ser um homem significa não ser como as mulheres” (KIMMEL, 1997, p. 52). As fronteiras parecem claras e dadas de antemão. Atravessá-las implica perda de “dividendos patriarcais”.

A combinação estreita entre masculinidades hegemônicas, paternidade como provimento material e o mito da maternidade, assente num dualismo de caráter essencialista, revela sua face mais perversa naquilo que, como mencionado acima, Connell (2005) chama de “dividendos patriarcais”, é dizer, vantagens à disposição dos homens em geral, conquanto acessíveis e usufruídos de forma profundamente heterogênea na concretude da vida cotidiana. Aqui, mais uma vez, (não só) gênero, classe e raça se cruzam, configurando obstáculos estruturalmente organizados a experiências maternas e paternas mais democráticas. Ou, como preferem Connell e Pearse (2015, p. 270), são os “dividendos patriarcais” o “principal pilar da política de gênero contemporânea”. A baixa participação das mulheres no espaço da representação política ${ }^{9}$ e as dificuldades que elas encontram no mercado de trabalho ${ }^{10}$ (MATOS; OLIVEIRA; NATIVIDADE, 2016; MATOS, 2015; OIT, 2016; MARQUES, 2015; CATTONI DE OLIVEIRA; MARQUES, 2017) são ilustrativas tanto daqueles dividendos como das conexões estreitas, embora mais ou menos ocultas ou ocultadas, entre a esfera doméstica e a esfera não doméstica.

O que foi dito até aqui parece conduzir à hipótese de que o triunfo de uma "revolução paternal”, tomando de empréstimo a expressão de Badinter (1993), não pode ser confiado (apenas) à boa vontade de mães e pais, mais ou menos comprometidas(os) com a igualdade de gênero. Sem o impulso de um arranjo institucional multifacetado e articulado, ainda em grande medida reprodutor

\footnotetext{
9 “[O]s homens estão representados em 81,5\% dos cargos no Senado, ocupam 90\% dos cargos da Câmara de Deputados, 89\% dos cargos das Assembleias Legislativas e Câmara Distrital, 96\% dos cargos de Governadores, em 89\% dos cargos das Prefeituras e 87\% das Câmaras Municipais no Brasil” (MATOS, 2015, p. 24).

10 É suficiente dizer que as mulheres "têm mais probabilidades de permanecerem ou virem a ficar desempregadas, têm menos oportunidades de participar no mercado de trabalho e - quando o conseguem - muitas vezes têm de aceitar empregos de qualidade inferior” (OIT, 2016, p. 3), o que favorece uma conjuntura global particularmente desfavorável a elas: as mulheres percebem 77 por cento da remuneração auferida pelos homens. Ainda segundo a Organização Internacional do Trabalho (2016), mantidas as tendências atuais, nas quais confluem desigualdades resistentes e progressos significativos, mais de 70 anos nos separam do fim das disparidades salariais.
} 
de concepções naturalizadas da maternidade e da paternidade, parece difícil imaginar uma reviravolta nas responsabilidades parentais. Chegamos, enfim, ao objeto central deste artigo.

A Constituição da República de 1988, porque atravessada, não só por representações tradicionais da maternidade e da paternidade, mas também por movimentos que subvertem estas representações, assegura às trabalhadoras licença-gestante de 120 dias e reconhece, pela primeira vez na história do constitucionalismo brasileiro, a licença-paternidade como direito fundamental, sem, contudo, estipular o prazo para o seu gozo $^{11}$. Enquanto pendente regulamentação do direito fundamental à licença-paternidade, como reclama a Constituição, prevalece o artigo 10, parágrafo primeiro, do Ato das Disposições Constitucionais Transitórias (ADCT) ${ }^{12}$, que fixa em cinco dias a duração da licença-paternidade.

Da promulgação da Constituição até aqui não foram poucas as tentativas de regulamentação desse direito fundamental. Empreendimentos mais ou menos frustrados, em parte, pelo tímido debate social em torno da licença-paternidade, só mais recentemente despertado aqui e ali; aspecto revelador do grau de enraizamento social de representações tradicionais que, a um só tempo, confinam a paternidade ao provimento material e entrelaçam feminilidade, maternidade, devotamento, cuidado e domesticidade. Contudo, dois avanços significativos recentes dão voz às tensões imanentes às experiências de homens e de mulheres no cuidado de crianças; o primeiro, a Lei ${ }^{0} 13.257 / 2016$, mais conhecida como Marco Legal da Primeira Infância ${ }^{13}$, e o segundo, o Decreto $n^{\circ}$ 8.737/2016. Enquanto o Marco Legal da Primeira Infância, entre outros aspectos, altera a Lei nº 11.770/2008 para prorrogar por quinze dias a duração da licença-paternidade, além dos cinco dias já fixados pelo ordenamento jurídico ${ }^{14}$, o Decreto n ${ }^{\circ} 8.737$, a seu passo, prorroga a licença-paternidade também por quinze dias

\footnotetext{
11 “Art. $7^{\circ}$ São direitos dos trabalhadores urbanos e rurais, além de outros que visem à melhoria de sua condição social: [...] XVIII - licença à gestante, sem prejuízo do emprego e do salário, com a duração de cento e vinte dias; XIX - licençapaternidade, nos termos fixados em lei” (BRASIL, 2016, p. 18).

12 "§ $1^{\circ}$ Até que a lei venha a disciplinar o disposto no art. $7^{\circ}$, XIX, da Constituição, o prazo da licença-paternidade a que se refere o inciso é de cinco dias” (BRASIL, 2016, p. 143).

${ }^{13}$ A Lei $n^{\circ}$ 13.257/2016 inova ao traçar princípios e diretrizes para a formulação e implementação de políticas públicas dirigidas à promoção e ao atendimento dos direitos das crianças de até seis anos. Cria a Política Nacional Integrada para a Primeira Infância, de caráter intersetorial, e corresponsabiliza União, Estados, Distrito Federal, Municípios, famílias e sociedade. O Marco Legal da Primeira Infância altera o Estatuto da Criança e do Adolescente (Lei no 8.069/1990) para, entre outros aspectos, expressamente responsabilizar mãe e pai, ou responsáveis, pelo cuidado e educação da criança. Também modifica a Consolidação das Leis do Trabalho (CLT) para assegurar ao empregado, sem prejuízo do salário, até dois dias para acompanhar consultas médicas e exames complementares no curso da gravidez de sua esposa ou companheira e um dia por ano para acompanhar filho de até seis anos em consulta médica. Resumidamente, a Lei $\mathrm{n}^{\circ}$ 13.257/2016 posiciona o pai como um dos agentes do processo de promoção da cultura do cuidado infantil. Densifica a igualdade constitucional na medida em que contribui com o processo de desconstrução de representações tradicionais da maternidade e da paternidade.

${ }^{14}$ A prorrogação beneficia pais biológicos ou adotivos empregados de pessoas jurídicas inscritas no Programa Empresa Cidadã. No período de prorrogação da licença-paternidade, semelhantemente ao que já previa a legislação nos casos de
} 
para os servidores regidos pela Lei n ${ }^{\circ}$ 8.112/1990, além dos cinco dias já definidos pelo art. 208 desta Lei $^{15}$. Em suma, avanços democráticos que revelam uma Constituição que, a um só tempo, ecoa e desestabiliza significados tradicionais da maternidade e da paternidade, da feminilidade e da masculinidade.

\section{A IDENTIDADE DO SUJEITO CONSTITUCIONAL: DELINEAMENTOS GERAIS}

Grosso modo, em The Constitutional Subject, its Other, and the Perplexing Quest for an Identity of its Own: A Reply to My Critics, Rosenfeld (2012, p. 1.938, tradução nossa) se debruça, sobre a questão da identidade constitucional e sua relação com o sujeito que lhe é correlato, num duplo sentido: “(1) quem se apropria ou pode se apropriar daquela identidade como sua própria; e (2) a quem se pode, ou a quem se deve atribuir aquela identidade”. A identidade do sujeito constitucional surge envolta em brumas e os desafios para os quais não só aponta, como aguça, se manifestam já no termo subject, ambíguo porque, em inglês, idioma em que foi formulada, pode se referir aos constituintes, às cidadãs e aos cidadãos sujeitos à Constituição ou, ainda, à matéria por ela coberta (subject matter). E as complicações não se esgotam aí. Entre aquelas mencionadas por Rosenfeld (2010), destacam-se (i) o desafio de se reconstruir uma narrativa coerente e plausível sobre uma identidade constitucional que se apoia sobre a reconciliação de um passado - o dos constituintes com um presente e um futuro, todos eles irremediavelmente abertos e incertos; (ii) a invencível incompletude do texto constitucional e a multiplicidade de interpretações e práticas constitucionais razoáveis que ele suscita; (iii) as emendas à Constituição, que podem tanto solapar como incrementar a identidade constitucional; (iv) a tensão entre o pluralismo constitucional e a tradição préconstitucional, manifesta no embate que opõe a Constituição, de caráter contratradicional, às demais identidades relevantes, de que são exemplos a identidade nacional, as identidades étnicas, religiosas ou culturais.

Por um lado, a identidade constitucional depende do repúdio dessas identidades relevantes. Ao negá-las, define, num primeiro movimento, um campo particular que lhe garante sobrevivência. Por outro lado, o repúdio, por si só, é insuficiente e temerário. E isso porque uma identidade constitucional despojada de todo e qualquer elemento de outras identidades, de tão abstrata se provaria imprestável. Aqui, movimentos de aproximação seletiva e de distanciamento tensionam a

\footnotetext{
prorrogação da licença-maternidade por dois meses, o empregado, que terá direito à remuneração integral, está proibido de exercer qualquer atividade remunerada, devendo manter a criança sob seus cuidados.

${ }^{15}$ O Decreto $n^{\circ}$ 8.737/2016, que institui o Programa de Prorrogação da Licença-Paternidade para os servidores regidos pela Lei nº 8.112/1990, também abrange casos de adoção e de obtenção de guarda judicial para fins de adoção de criança.
} 
interação entre a identidade constitucional e as identidades nacionais, regionais, étnicas, religiosas e culturais. Essa é a questão-chave da dinâmica sobre a qual Rosenfeld (2010) se detém: a identidade constitucional transita entre as demais identidades relevantes, incorporando e reconstruindo alguns de seus elementos. Precisamente por isso, e antecipando os desdobramentos a seguir, a identidade do sujeito constitucional emerge “como algo complexo, fragmentado, parcial e incompleto”, como “o produto de um processo dinâmico sempre aberto à maior elaboração e à revisão” (ROSENFELD, 2003a, p. 23). Falamos da identidade e do sujeito constitucionais como ausência ${ }^{16}$. Longe de uma fonte última de legitimidade e de autoridade para a ordem constitucional, deparamo-nos com um hiato, um vazio, um não lugar.

\section{A RECONSTRUÇÃO DA IDENTIDADE DO SUJEITO CONSTITUCIONAL: DA PATERNIDADE TRADICIONAL ÀS PATERNIDADES CONSTITUCIONAIS}

Diferentemente da ordem política pré-moderna, o constitucionalismo moderno ${ }^{17}$, dado o pluralismo que lhe é imanente, lança já aos constituintes a tensão, a um só tempo, inarredável e insolúvel entre o eu (self) e o outro, entre a identidade e a diferença, entre a coerção e a emancipação e entre a herança sociocultural e a sua reinvenção constitucional. O pluralismo impõe aos constituintes o desafio de lapidar uma identidade constitucional não confinada em sua própria subjetividade. Há, aqui, uma experiência de alienação do poder. Longe daquelas leituras que enxergam a possibilidade de criação de um mundo político ex nihilo pelos constituintes, Rosenfeld (2010) fala de um sujeito constitucional carente e alienado, limitado pelo passado, pelo presente e pelo futuro.

Da perspectiva dos constituintes, a identidade constitucional surge como um vazio entre sua subjetividade e a comunidade política constitucional pluralista. Aliás, a elaboração da Constituição pode ser considerada, escreve Rosenfeld (2010, p. 36, tradução nossa), “uma tentativa de preencher esse vazio, esse hiato, mediante o alcance do outro para forjar uma identidade comum enraizada em um texto constitucional compartilhado”. Tentativa que se arrasta ao longo da vigência da Constituição. E isso porque o sujeito constitucional atua mediante um discurso particular, o discurso

\footnotetext{
${ }^{16}$ A concepção da identidade do sujeito constitucional como ausência, tal como esboçada por Rosenfeld (2010, p. 36, tradução nossa), aproxima-se de teorias filosófica e psicanalítica do sujeito, destacadamente, Hegel, Freud e Lacan: “[t]omadas em conjunto, essas teorias postulam que a construção e a reconstrução da identidade ocorrem no contexto de uma luta entre o eu e o outro, e que a busca do sujeito por uma identidade significativa depende de usos combinados bemsucedidos de três ferramentas interpretativas: negação, metáfora e metonímia”.

${ }^{17}$ O Constitucionalismo, escreve Carvalho Netto (2002, p. 69), "se traduz [em último termo] na permanente tentativa de se instaurar e de se efetivar concretamente a exigência idealizante que inaugura a modernidade no nível da organização de sua sociedade complexa a qual não mais pode lançar mão de fundamentos absolutos para legitimar o seu próprio sistema de direitos e a sua organização política: a crença de que constituímos uma comunidade de homens livres e iguais, co-autores das leis que regem o nosso viver em comum”.
} 
constitucional, construído a partir de um texto constitucional e vinculado a um contexto específico. O sujeito constitucional, porque tem de recorrer ao discurso constitucional, experiencia-se, outra vez mais, alienado. Alienado porque a linguagem constitucional que o sujeito constitucional invoca se diferencia da linguagem tanto do eu como do outro, sujeitando ambos aos seus próprios termos, quais sejam, governo limitado, Estado de Direito (rule of law) e proteção dos direitos fundamentais. É a partir do discurso constitucional que se constrói uma identidade abrangente do eu e do outro; comum tanto ao sujeito constitucional multifacetado como aos diferentes outros.

E quem é o sujeito constitucional? Ainda que constituintes, intérpretes da Constituição e cidadãos sobre os quais pesam as normas constitucionais integrem o sujeito constitucional, nenhum deles o monopoliza. Ou, como diz Salcedo Repolês (2004, p. 155), “[s]e a identidade do sujeito constitucional depende da construção do discurso constitucional, ela é inerentemente intersubjetiva, como o é o próprio discurso”. E mais, “[i]sso quer dizer que a relação entre o Eu e o Outro passa a fazer parte integrante e irredutível do próprio conceito de sujeito constitucional”. Assim, precisamente porque é na arena intersubjetiva, mediada pelo discurso constitucional, em que despontam fragmentos da identidade do sujeito constitucional, não é o caso de personificá-lo, privatizá-lo ou esgotá-lo, adverte Rosenfeld (2010, p. 40-41, tradução nossa): “o sujeito constitucional enquanto tal só pode ser apreendido mediante expressões de sua autoidentidade no discurso intersubjetivo que vincula todos os atores humanos que estiveram, estão e serão reunidos pelo mesmo conjunto de normas”.

Em sua plenitude, a autoidentidade constitucional é inacessível ao sujeito constitucional, que se vê condenado a apenas tatear sua própria identidade e se em jogo um exercício de imaginação capaz de agasalhar, articular e condensar elementos projetados em direções distintas, ao passado, ao presente e ao futuro. Na construção de uma narrativa coerente e plausível, quem quer que assuma a posição de sujeito constitucional enxerga apenas parcial e fragmentariamente tanto o sujeito constitucional do qual toma parte como a autoidentidade constitucional, porque histórica e empiricamente constrangido. A impossibilidade de uma determinação exaustiva quer do sujeito constitucional, quer da identidade constitucional decorre também do fato de que "[s]ó podemos observar algo com os olhos que temos, marcados socialmente e historicamente datados, e não com supostos olhos divinos e atemporais. Nossos olhos”, continua Carvalho Netto (2003a, p. 151), "são sempre os olhos de uma sociedade determinada, de determinada época”. A respeito das gerações que o precederam e das vindouras, o sujeito constitucional alcança, quando muito, meros vestígios. Meros vislumbres. 
“[A] autoidentidade constitucional”, escreve Rosenfeld (2010, p. 42, tradução nossa) “só pode ser articulada pouco a pouco por um sujeito parcial que deve construí-la a partir de fragmentos díspares que precisam ser projetados em um passado e em um futuro incertos”. Precisamente por isso, a construção, que alcança, quando muito, vestígios e vislumbres da identidade constitucional, reclama outro movimento: a reconstrução. Deve-se suplementar a construção com uma reconstrução da identidade constitucional, que dá contornos mais precisos àqueles vestígios. Com a reconstrução, aqueles vislumbres tornam-se mais nítidos, embora jamais definitivos.

Antinomias como real e ideal ajudam a explicar a relação entre construção e reconstrução. Recuperando o que foi mencionado acima, as limitações históricas e empíricas que inevitavelmente pesam sobre o sujeito constitucional o impedem de encontrar na sua (pobre) realidade um fundamento para a ordem constitucional. "Dada a pobreza inerente do real, é necessário recorrer ao ideal para formular uma concepção adequada da autoidentidade constitucional. Sem dúvida”, argumenta Rosenfeld (2010, p. 43, tradução nossa), “na medida em que do nosso próprio ponto de vista historicamente limitado não podemos enxergar o 'eu’ constitucional de que somos parte, buscamos imaginá-lo”. Aqui, o ideal suplementa o real. Não sem riscos, como veremos mais adiante. Nos processos de tomada de decisão, a reconstrução constitucional opera ora como justificativa normativa do status quo, ora como denúncia das instituições vigentes. No primeiro caso, ideal e real aproximamse; no segundo, ideal e real contrapõem-se.

Assim, pelo discurso constitucional, assentado sobre um texto constitucional particular, é que se dão contornos mais precisos, embora insaturáveis, à identidade e ao sujeito constitucionais. Também se recorre ao discurso constitucional com outro propósito: explorar o hiato que distancia uma ordem constitucional particular dos imperativos normativos do constitucionalismo, ora para forjar algum tipo de harmonia, ora para revelar algum descompasso, uma defasagem mais ou menos profunda. Trata-se, aqui, de outra das antinomias ilustrativas da relação entre construção e reconstrução: a antinomia entre fatos e normas. É dizer, “um confronto entre a facticidade de uma certa Constituição em particular e as normas que definem o que uma democracia constitucional deveria ser” (ROSENFELD, 2010, p. 42, tradução nossa).

O discurso constitucional, em todas as hipóteses acima aludidas, ganha corpo quando entra em cena o instrumental reconstrutivo da negação, da metáfora e da metonímia, ferramentas distintas, mas estreita e tensamente interligadas. Quer isso dizer que, se novos elementos entram em jogo quando se interpreta a Constituição, é pela reconstrução que se harmonizam, se reajustam, se reacomodam ou se recompõem os elementos em questão, os elementos tradicionais e os não tradicionais. É também por meio da negação, da metáfora e da metonímia que se opera a afirmação 
de direitos fundamentais e a correlata delimitação dos titulares desses direitos. Uma vez visibilizados incluídos e excluídos da titularidade de direitos, podem os últimos, valendo-se também daquele mesmo instrumental, organizar-se e lutar "pela conquista de concepções cada vez mais complexas e articuladas da afirmação constitucional da igualdade e da liberdade de todos” (CARVALHO NETTO, 2003a, p. 145).

\subsection{NEGAÇÃO}

Num primeiro movimento, a identidade do sujeito constitucional encarna uma identidade puramente negativa. E isso porque a negação de todas as outras identidades em jogo é condição para o seu aparecimento enquanto identidade distinta. É dizer, sem a negação do passado préconstitucional e das peças extraconstitucionais, a identidade constitucional ou se confundiria com outras identidades ou surgiria como uma identidade secundária, um mero desdobramento daquelas identidades, aqui recalcadas, reprimidas ou abandonadas. Ocorre que esta negação, por si só, é insuficiente. Assim, outros dois movimentos conformam o processo pelo qual se estabelece e se articula, não sem tensões, a identidade constitucional.

Na medida em que o sujeito constitucional emerge envolto no vazio e na carência, ele se vê forçado a lutar por uma identidade positiva. Em poucas palavras, "por perturbar o status quo e por desenraizar significados assentados, a negação cria um vácuo que deve ser preenchido” (ROSENFELD, 2010, p. 60, tradução nossa). Se, num primeiro movimento, o sujeito constitucional nega as identidades nacionais, regionais, linguísticas, religiosas, éticas, políticas e ideológicas, agora ele se vê impelido a voltar sua atenção para elas, afinal "os objetivos do constitucionalismo não podem ser perseguidos no vácuo; eles reclamam o estabelecimento de um aparato institucional viável, que deve, necessariamente, se acomodar na história, nas tradições, no patrimônio cultural da comunidade política relevante” (2010, p. 47, tradução nossa). Voltar-se para elas, contudo, não significa abrir mão da identidade constitucional.

Em outras palavras, a identidade constitucional cede sem se dobrar àquelas identidades. $\mathrm{E}$ isso porque são os interesses do constitucionalismo que orientam o retorno, sempre seletivo, às identidades nacionais, regionais, linguísticas, religiosas, éticas, políticas e ideológicas inicialmente descartadas. Sempre seletivo porque as identidades são reposicionadas e os seus elementos recombinados pelo sujeito constitucional no interior da ordem constitucional emergente. Dito diferentemente, movimentos postos em marcha não só preservam aquelas identidades como também as transcendem. Aqui, o sujeito constitucional novamente se defronta com uma tensão, mais 
especificamente, entre a sobrevivência e a manutenção da identidade. Aliena-se porque se vê mediado pelas identidades outrora profanadas: “com o desenrolar do processo de incorporação daquelas identidades, o sujeito constitucional torna-se presa de influências externas que parecem estar fora de seu controle” (ROSENFELD, 2010, p. 48). Um terceiro movimento entra em cena quando o sujeito constitucional se dá conta de que a construção da identidade constitucional não opera a partir da perda da subjetividade, diferentemente do que parece sugerir o movimento precedente. Quer isso dizer que ainda que o sujeito constitucional, para forjar uma identidade distinta, trabalhe com outras identidades relevantes, material que transborda a arena constitucional, são os limites do constitucionalismo que, em última instância, orientam e conformam o seu trabalho.

Lido retrospectivamente, o reconhecimento constitucional do direito fundamental à licençapaternidade implica um corte na paternidade tradicional ou pré-constitucional, aquela variante da paternidade que se confunde com o encargo do provimento material. A Constituição, de caráter contratradicional, reprime, rejeita, recalca a variante tradicional/pré-constitucional da paternidade. Da negação da paternidade tradicional, contudo, emerge um vazio, uma ausência que demanda preenchimento, favorecendo um retorno seletivo, porque sujeito ao constitucionalismo, àquela versão da paternidade anteriormente abandonada. Os elementos da paternidade tradicional são recombinados conforme certos compromissos do constitucionalismo democrático, a exemplo da igualdade de gênero. O reconhecimento de uma licença para os pais como direito fundamental, e não apenas para as mães, ilustra este movimento. Daí por que enxergar o processo constituinte de 1987-88 como o ponto de partida de um movimento de reconstrução constitucional das paternidades em um nível relativamente alto de abstração. Relativamente alto porque, em alguma medida, a constitucionalização da licença-paternidade denuncia e se contrapõe à distância historicamente construída entre maternidade e paternidade. É dizer, a constitucionalização da licença-paternidade pode ser retrospectivamente lida como uma investida contra a naturalização da paternidade e da maternidade. O Projeto Constituinte de 1988 põe em marcha um movimento de desessencialização do "ser pai” e do "ser mãe”.

A investida de que falamos aparece no relato de Pitanguy (2011, p. 25) sobre a disputa entre concepções rivais da paternidade no curso do processo constituinte de 1987-88, período que coincide com sua liderança no Conselho Nacional dos Direitos da Mulher (CNDM): “[q]uando apresentamos a proposta de licença-paternidade, fomos duramente criticadas e até mesmo ridicularizadas por amplos setores do Congresso Nacional. Argumentavam”, continua ela, “que estaríamos incentivando a ausência dos homens do trabalho. Estávamos, no entanto, convencidas da relevância desta licença como um instrumento de mudança ideológica no papel dos homens frente à paternidade”. 
O discurso proferido pelo Constituinte Alceni Guerra, autor da emenda da licençapaternidade, é também elucidativo da tensão entre a subjetividade dos Constituintes e a comunidade política constitucional pluralista ali forjada, das identidades e diferenças em jogo e da fratura que se pretendia promover, não sem controvérsias, na concepção tradicional da paternidade. Em seu discurso combativo, Guerra reage ao deboche de alguns de seus pares, ainda presos a uma concepção particularmente pobre da paternidade ${ }^{18}$. Sua fala também acena para a reinvenção constitucional da paternidade que emerge ali, no curso do processo constituinte de 1987-88, e para as tensões de um projeto desse tipo:

Suas origens [o Constituinte se refere aqui à emenda da licença-paternidade], Sr. Presidente, remontam à época em que eu era médico-pediatra, há 10 ou 12 anos. Frequentemente deparava-me com uma mulher que, tendo acabado de dar à luz a um filho, e estando impossibilitada de assisti-lo, não podia ter ao seu lado o marido, o companheiro, o pai da criança que, naquele momento, era muito importante para a preservação, Srs. Constituintes, da família, que considero a cellula mater da sociedade. [...] Confesso a V.Exas., com muita humildade, que tive vergonha de apresentar esta emenda na fase da Subcomissão, da Comissão e da Comissão de Sistematização. Mas Deus me ajudou num caso muito particular. No dia 14 de dezembro de 1987, quando nasceu minha filha Ana Sofia, para minha infelicidade, minha mulher esteve à beira da morte e depois passou 3 semanas imobilizada no leito por um acidente anestésico. Sr. Presidente, não havia no mundo naquele instante nenhuma Assembleia Nacional Constituinte, nenhum emprego, nenhum patrão, nenhuma força do mundo, nada que me tirasse do lado dela e dos meus filhos. (Palmas.) Por algumas semanas fui pai dedicado, amigo, aprendi a brincar, reaprendi a pintar, a cantar, a acompanhar meus filhos Guilherme Guerra, Pedro Guerra, Maria Pia, Ana Sofia e minha esposa. Mão na mão. Mão de marido, de pai, de companheiro, do homem responsável” (BRASIL, 1988, p. 7.664).

A constitucionalização da licença-paternidade desenraiza, não sem tensões, os significados da paternidade de suas matrizes históricas. Ao reconstruí-los, resgata sua historicidade, ajusta-os ao contexto mutável e às suas demandas mais ou menos prementes, amolda-os aos imperativos do constitucionalismo democrático. E uma vez suspensas as paternidades (e, inevitavelmente, também as maternidades) de seu passado pré-constitucional, passam elas a ocupar uma posição destacadamente nova, agora submetida aos interesses da ordem constitucional e do constitucionalismo.

Com a promulgação da Constituição de 1988, aqui tomada como ponto de partida, as paternidades se abrem a novos desdobramentos, a novas reconstruções. É isso o que está em jogo nas tentativas de regulamentação do direito fundamental à licença-paternidade. Os passos dados adiante

\footnotetext{
${ }^{18}$ Ao anunciar a proposição da licença-paternidade, Ulysses Guimarães, Presidente da Assembleia Constituinte, graceja com a proposta, provocando o riso de alguns dos Constituintes: "[t]rata-se de uma homenagem ao homem gestante. (Palmas). Como justificativa da proposição, podíamos lembrar o que disse o talentoso Chico Anísio: há o dia da mãe, e o dia do homem é precisamente nove meses antes do dia da mãe. Acho que ela não precisa ser justificada, porque é evidente a alegria dos homens que aqui se encontram diante desta proposição” (BRASIL, 1988, p. 7.663).
} 
focalizam a metáfora e a metonímia, outras duas ferramentas reconstrutivas trabalhadas por Rosenfeld (2010). Mais especificamente, interessa-nos identificar como elas operam tanto nas propostas legislativas que ampliam o direito fundamental à licença-paternidade ${ }^{19}$, como nos pareceres de parlamentares nas Comissões da Câmara dos Deputados. Com isso pretende-se avaliar se os discursos constitucionais que reconstroem concepções da paternidade atualizam ou subvertem elementos tradicionais da paternidade e da maternidade. Pretende-se também identificar se aqueles discursos promovem ou ocultam rearranjos familiares mais equitativos, ainda tímidos, mas já em curso. Enfim, interessa-nos saber se as reconstruções da paternidade favorecem ou estorvam a igualdade de gênero, que tipos de paternidade são promovidos ou admitidos. E que variantes são eclipsadas. E mais, que imagens da identidade constitucional são ali projetadas.

\subsection{METÁFORA}

Uma vez definida a identidade constitucional por aquilo que ela não é, movimento que se confunde com a experiência do vazio, a metáfora e a metonímia dão continuidade ao trabalho da negação ao pôr em marcha a dialética entre identidade e diferença. Assim, projetam-se imagens de uma identidade constitucional, enfim, positiva, pouco a pouco preenchida. Transbordante. E isso porque há sempre expectativas e compreensões ocultas e ocultadas. A metáfora, mediante movimentos de combinação e substituição, desvenda, explora e destila semelhanças, correspondências, costura vínculos comuns ao preço do descaso, sempre parcial e temporário, com as diferenças. Ou, como diz Rosenfeld (2010, p. 51, tradução nossa), “[e]nquanto uma ferramenta desenhada para estabelecer semelhanças e equivalências, a metáfora fornece a base discursiva ao polo da identidade na dialética entre identidade [...] e diferença”.

A metáfora é uma ferramenta, a um só tempo, valiosa e perigosa. As vantagens e os riscos inerentes ao aparato metafórico podem ser claramente percebidos quando nos debruçamos sobre as controvérsias ligadas à promoção da igualdade de gênero. Por um lado, o raciocínio metafórico, ao invocar similaridades entre homens e mulheres, em detrimento das diferenças que supostamente os particularizariam, legitima a redivisão constitucional dos encargos domésticos e familiares. Neste caso, forja-se uma identidade fundamental compartilhada por todos os seres humanos. Este é o caso

\footnotetext{
${ }^{19}$ Limitamo-nos ao exame daquelas propostas legislativas que ampliam a licença-paternidade independentemente da referência à eventual ausência da figura materna. E isso porque condicionar a ampliação da licença-paternidade a hipóteses de invalidez permanente ou temporária, abandono ou falecimento da mãe (a exemplo dos Projetos de Lei 6.753/2010, 3.212/2012, 3.231/2012, 3.281/2012, 3.417/2012, 3.445/2012, 5473/2013, 5.566/2013) parece antes atualizar concepções naturalizadas da maternidade e da paternidade do que desestabilizá-las.
} 
dos discursos que defendem a ampliação da licença-paternidade contra o pano de fundo de uma sociedade tradicionalmente patriarcal, é dizer, em que diferença implica desigualdade. Por outro lado, o pensamento metafórico, precisamente porque tende à descontextualização, pode eclipsar diferenças que fazem diferença: o reconhecimento de medidas concretas que favoreçam, a título de exemplo, a participação das mulheres nos espaços da política institucionalizada esbarra no pensamento metafórico que superenfatiza a igualdade entre homens e mulheres perante e sob o Direito. O artigo $5^{\circ}$, inciso I, da Constituição da República, que enuncia a igualdade entre homens e mulheres ${ }^{20}$, quando combinado com o encobrimento da divisão sexual do trabalho, largamente enraizada e particularmente desvantajosa para as mulheres, resulta numa concepção mais excludente de igualdade ou, mais especificamente, de igualdade de gênero. Dessa combinação se desdobra um endosso de um esquema que beneficia os homens em geral em detrimento das mulheres em geral, atualizando aquilo que Connell (2005) chama de “dividendos patriarcais”. Resumidamente, abstrair as diferenças em jogo ora densifica, ora restringe a igualdade de gênero.

Dito isso, enfoquemos o que mais interessa a este ensaio: a reconstrução da concepção tradicional da paternidade. A metáfora aparece recorrentemente nas justificativas dos projetos de lei que ampliam o direito fundamental à licença-paternidade para quinze ou trinta dias nas hipóteses de nascimento ou adoção. E isso porque a metáfora perturba as fronteiras historicamente forjadas como autoevidentes entre maternidade e paternidade ou feminilidade e masculinidade; subverte processos de naturalização e aguçamento das diferenças. É elucidativo disso argumentos como os do Projeto de Lei $n^{\circ} 3.325 / 2012^{21}$, que, citando a pesquisadora Sandra Unbehaum, equipara “a importância da presença do pai [à da mãe] na vida do filho [...], tendo como única diferença a questão da amamentação” (CÂMARA DOS DEPUTADOS, 2012b).

Aqui, a reconstrução das paternidades surge como elemento-chave de um processo mais amplo de reconstrução constitucional e democrática da ordem de gênero. Duas proposições são particularmente ilustrativas disso. O Projeto de Lei nº 3.325/2012, ao propor a ampliação da licençapaternidade, acredita, entre outros aspectos, “contribuir com a partilha de funções entre os sexos desde cedo, desenvolvendo uma paternidade mais presente e participativa” (CÂMARA DOS

\footnotetext{
20 “Art. 5 $5^{\circ}$ Todos são iguais perante a lei, sem distinção de qualquer natureza, garantindo-se aos brasileiros e aos estrangeiros residentes no País a inviolabilidade do direito à vida, à liberdade, à igualdade, à segurança e à propriedade, nos termos seguintes: (EC no 45/2004) I - homens e mulheres são iguais em direitos e obrigações, nos termos desta Constituição” (BRASIL, 2016, p. 13).

${ }^{21}$ Proposto pelo então Deputado Edivaldo Holanda Júnior (PTC/MA), o Projeto de Lei no 3.325/2012 “[r]egulamenta a licença-paternidade a que se refere o artigo $7^{\circ}$, inciso XIX, da Constituição Federal” (CÂMARA DOS DEPUTADOS, 2012b).
} 
DEPUTADOS, 2012b). Semelhantemente, o Projeto de Lei $n^{\circ} 1.131 / 2015^{22}$, apoiado (não só) sobre a metáfora, trabalha o descompasso entre um contexto particular, já ressignificador das paternidades, e certos dispositivos constitucionais. Propõe, então, uma adequação constitucional “aos tempos modernos em que o pai não é mais tão somente o provedor [...] [mas] um dos pilares de sustentação, sendo parte atuante e essencial na assistência, criação e educação dos filhos bem como de toda a família” (CÂMARA DOS DEPUTADOS, 2015).

Em ambos os casos, a metáfora se combina com a negação para forjar uma nova concepção da paternidade. Aqui, negação e metáfora atuam para reprimir a paternidade tradicional, aquela variante da paternidade absorvida pelo encargo do provimento material, e para reinventar a paternidade num nível relativamente alto de abstração. Ou seja, as identidades são superenfatizadas à custa das diferenças. Isso é também identificado no Voto em separado do então Deputado Eudes Xavier (PT/CE) ${ }^{23}$, aqui sintetizado no argumento de que “[o]s pais, além de serem afetivamente importantes para os filhos também são aptos para propiciar a atenção necessária, especialmente nos primeiros dias de vida” (CÂMARA DOS DEPUTADOS, 2013c).

A reconfiguração sexual do mercado de trabalho é outro aspecto decisivo nas tentativas de reconstrução das paternidades. É o caso do Voto em separado do então Deputado Assis Melo (PCdoB/RS) 24: “[o] evidente aumento exponencial da participação das mulheres no mercado de trabalho e nas organizações políticas e sindicais traz a necessidade de que o homem participe mais ativamente na criação dos filhos” (CÂMARA DOS DEPUTADOS, 2013b). Aqui, o contexto social surge mais uma vez como limite para o trabalho metafórico, que privilegia as semelhanças entre o “ser pai” e o “ser mãe”. É dizer, certas relações contíguas, certas particularidades circunscrevem o nível adequado de abstração a ser alcançado na reconstrução das paternidades.

\subsection{METONÍMIA}

A metonímia, a seu passo, segue o curso inverso. Operando movimentos de contextualização, faz falar as diferenças e especificidades eleitas relevantes num dado momento;

\footnotetext{
${ }^{22}$ O Projeto de Lei no 1.131/2015, proposto pelo Deputado Rôney Nemer (PP/DF), “[a]ltera dispositivos da Consolidação das Leis do Trabalho, aprovada pelo Decreto-Lei $\mathrm{n}^{\circ}$ 5.452, de $1^{\circ}$ de maio de 1943, para ampliar a licença-paternidade para trinta dias" (CÂMARA DOS DEPUTADOS, 2015).

${ }^{23}$ O Voto em separado do então Deputado Eudes Xavier (PT/CE), concernente aos PL 3.935/2008, 4.853/2009 e 4.913/2009, rebate o parecer do Relator, Deputado Silvio Costa (PTdoB/PE), pela rejeição da ampliação da licençapaternidade na Comissão de Trabalho, de Administração e Serviço Público (CTASP).

${ }^{24}$ O Voto em separado do então Deputado Assis Melo (PCdoB/RS), relativo aos PL 3.935/2008, 4.853/2009 e 4.913/2009, discorda do parecer do Relator, Deputado Silvio Costa (PTdoB/PE), pela rejeição da ampliação da licença-paternidade na Comissão de Trabalho, de Administração e Serviço Público (CTASP).
} 
escolhas, a propósito, mais ou menos contestadas porque as identidades e as diferenças são construídas, jamais dadas. As proposições legislativas aqui trabalhadas são extraordinariamente elucidativas disso. Sua própria condição de possibilidade reside no fato de que, longe de configurar categorias naturais, monolíticas ou fixas, podemos construir, desconstruir e reconstruir as paternidades, as maternidades, as masculinidades e as feminilidades; resumidamente, trabalhamos com a historicidade do gênero. Falamos de um conteúdo permanentemente em disputa.

Assim como as identidades, as diferenças prestigiadas do ponto de vista constitucional e legal são antes artificiais, abertas e contingentes do que reais, categóricas, estáticas ou monolíticas. É por isso que Rosenfeld (2003b) se refere a elas como "artifícios sociais", muito embora recorrentemente se tente ocultar o caráter artificial das identidades e das diferenças sob o véu da natureza ou da biologia. Argumentos que apelam às diferenças naturalizadas (reificadas e reificadoras) entre homens e mulheres, particularmente encarnadas na gravidez e na amamentação, são ilustrativos dessa tentativa de encobrimento da artificialidade das identidades e das diferenças. Este é o caminho percorrido pelos opositores de certas interpretações e práticas constitucionais, como aquelas que desestabilizam concepções tradicionais da paternidade.

Precisamente porque a igualdade requer antes proporcionalidade do que mera similaridade de tratamento e porque a identidade constitucional não se confunde com dinâmicas de similitude, tampouco se reduz a elas, o aparato metonímico surge para superenfatizar as singularidades mais minuciosas, as particularidades mais miúdas. Dado o pluralismo imanente ao constitucionalismo, a identidade do sujeito constitucional cobra mais do que similaridade: “[p]recisamente porque [...] deve colmatar o vazio entre o eu e o outro, ela deve incorporar as diferenças mediante contextualização para afastar a subordinação de uns aos outros no interior do mesmo regime constitucional” (ROSENFELD, 2010, p. 56, tradução nossa).

Assim como a metáfora, a função metonímica também justifica reconstruções constitucionais, densifica direitos fundamentais e dá contornos mais claros, embora de todo modo precários, à identidade constitucional. Já foi possível entrever que metáfora e metonímia podem ser empregadas tanto para incorporar novos direitos fundamentais como para alargar ou restringir direitos fundamentais já reconhecidos. Em ambos os casos estão em jogo embates sobre o alcance e a natureza dos direitos fundamentais, encarnados numa luta em torno da identidade e da diferença.

O caminho metonímico é privilegiado, como já antecipado, pelos pareceres que rejeitam qualquer ampliação da licença-paternidade. Ao ver do Relator Júlio Delgado (PSB/MG), em Parecer 
na Comissão de Desenvolvimento Econômico, Indústria e Comércio (CDEIC) ${ }^{25}$, as diferenças de caráter “fisiológic[o]” justificam a ordem vigente que prevê cinco dias para a licença-paternidade. Para o Relator, é “notório que o vínculo entre a criança e a mãe é o mais forte” (CÂMARA DOS DEPUTADOS, 2013a). Aqui, o eixo metonímico é trilhado na reconstrução de um âmbito de proteção restrito da igualdade constitucional. É isso o que revela a pressuposição de fronteiras rígidas, intransponíveis e naturalizadas entre masculinidades e feminilidades ou, mais especificamente, entre paternidades e maternidades. Deste tipo de reconstrução desdobra-se um apoio à ideia largamente arraigada do trabalho reprodutivo como destino compulsório da mulher: “a igualdade jurídica e intelectual entre homens e mulheres”, conforme o Parecer, “não afasta a natural diferenciação fisiológica e psicológica dos sexos”. A paternidade surge, então, absorvida pela responsabilidade financeira, uma vez que, embora “[a] presença do pai influenci[e] positivamente no crescimento da criança, [...] a mãe, com a garantia de poder permanecer ao lado do filho, supre esta necessidade propiciando ao bebê o vínculo afetivo necessário ao seu desenvolvimento muito antes do seu nascimento” (CÂMARA DOS DEPUTADOS, 2013a).

E se a paternidade se confunde com o provimento material, proteger a paternidade significa "garantir [...] ao pai a possibilidade de executar suas tarefas profissionais após a chegada do filho, [...] para que este faça frente à manutenção das despesas familiares, agora majoradas em razão deste nascimento”. Consequentemente, a rejeição da ampliação da licença-paternidade aparece como forma de se assegurar a "satisfação e realização pessoal e profissional [do pai], o que, consequentemente”, a juízo do Relator, “trará benefício a todos os integrantes daquela unidade familiar” (CÂMARA DOS DEPUTADOS, 2013a).

Elementos tradicionais da paternidade e da maternidade também são recuperados pelo Parecer do Relator Silvio Costa (PTB/PE), na Comissão de Trabalho, de Administração e Serviço Público (CTASP) ${ }^{26}$. Embora reconheça a influência positiva da presença paterna, afirma o Relator que “a mãe, com a garantia de poder permanecer 6 (seis) meses ao lado do filho, supre essa necessidade, propiciando ao bebê vínculo afetivo necessário ao seu desenvolvimento desde o primeiro momento do seu nascimento” (CÂMARA DOS DEPUTADOS, 2012a). Como se pode notar, nos discursos acima destacados, o trabalho reconstrutivo, estruturado sobretudo a partir da metonímia,

\footnotetext{
${ }^{25}$ O parecer do Relator, Deputado Júlio Delgado (PSB-MG), na Comissão de Desenvolvimento Econômico, Indústria e Comércio (CDEIC), pela rejeição da ampliação da licença-paternidade, se refere aos PL 6.753/2010, 879/2011, 2.098/2011, 2.272/2011, 2.967/2011, 3.212/2012, 3.231/2012, 3.281/2012, 3.325/2012, 3.417/2012, 3.431/2012, 3.445/2012, 3.831/2012, 5.473/2013, 5.566/2013, 5.797/2013, 5.920/2013.

${ }^{26}$ O parecer do Relator, Deputado Silvio Costa (PTdoB/PE), na Comissão de Trabalho, de Administração e Serviço Público (CTASP), pela rejeição da ampliação da licença-paternidade, se refere aos PL 3.935/2008, 4.853/2009 e $4.913 / 2009$.
} 
opera como apoio normativo às instituições vigentes. Forja-se uma harmonia entre o real e o ideal, entre normas de uma Constituição específica e os requisitos normativos do constitucionalismo e entre uma Constituição e certos fatos sociopolíticos e históricos relevantes.

Aqui, percorrer o eixo metonímico implica subordinar a mulher à função materna naturalizada e desresponsabilizar o homem de qualquer dimensão para além do sustento material da família. Movimento em dissintonia com o ingresso em massa das mulheres no mercado de trabalho e com práticas paternas e maternas desviantes daquele desgastado modelo familiar construído entre os séculos XIX e XX, o da família nuclear burguesa. O apelo à metonímia, encarnado na defesa de concepções tradicionais da paternidade e da maternidade, combina-se com relativa abstração das múltiplas configurações e dinâmicas familiares, é dizer, ocultam-se arranjos familiares destoantes do modelo familiar tornado hegemônico nos últimos séculos.

\section{CONSIDERAÇÕES FINAIS: A INTERAÇÃO IMBRICADA ENTRE NEGAÇÃO, METÁFORA E METONÍMIA. RISCOS, LIMITES E POTENCIAIS EMANCIPATÓRIOS}

Em muitos dos projetos de lei acima examinados, negação, metáfora e metonímia se intermesclam em movimentos de denúncia das instituições vigentes. E isso porque, como vimos, a produção de sentido depende de uma dupla referência, à metáfora e à metonímia, podendo uma delas ser privilegiada em face da outra dependendo dos objetivos perseguidos. Três deles, o Projeto de Lei $n^{\circ} 3.935 / 2008$, originalmente Projeto de Lei do Senado $n^{\circ} 666 / 2007^{27}$, o Projeto de Lei $n^{\circ} 879 / 2011^{28}$ e o Projeto de Lei ${ }^{\circ} 4.878 / 2016^{29}$, enfatizam, recorrendo à metáfora, a importância da ampliação da licença-paternidade para a construção de "vínculo seguro, de afeto e responsabilidade, com os filhos" (SENADO FEDERAL, 2007).

Todos os Projetos analisados desconstroem, em alguma medida, as diferenças historicamente forjadas entre maternidade e paternidade. Para tanto, o cruzamento entre negação e metáfora é decisivo. O argumento do Deputado Franklin Lima (PP/MG) é ilustrativo dessa imbricação: “[a] dilatação do tempo de licença é medida que pode colaborar para modificar a noção

\footnotetext{
${ }^{27}$ Proposto pela então Senadora Patrícia Saboya (PDT/CE), o Projeto de Lei do Senado no 666/2007 "[r]egulamenta a licença-paternidade [de quinze dias] a que se refere o inciso XIX, do art. $7^{\circ}$, da Constituição Federal” (SENADO FEDERAL, 2007).

${ }^{28}$ O Projeto de Lei n ${ }^{\circ}$ 879/2011, da Deputada Érika Kokay (PT/DF), “[a]crescenta art. 473-A ao Decreto-Lei nº 5.452, de $1^{\circ}$ de maio de 1943, que aprova a Consolidação das Leis do Trabalho, para estipular em 30 (trinta) dias a licençapaternidade” (CÂMARA DOS DEPUTADOS, 2011).

${ }^{29}$ O Projeto de Lei $n^{\circ}$ 4.878/2016, de autoria do Deputado Franklin Lima (PP/MG), “[a]ltera a redação do inciso III, do art. 473 da Consolidação das Leis do Trabalho, aprovada pelo Decreto-lei n. ${ }^{\circ}$ 5452, de $1^{\circ}$ de maio de 1943, e o artigo 208, da Lei $n^{\circ}$. 8.112, de 11 de dezembro de 1990, para definir a duração [de 30 dias] da licença paternidade” (CÂMARA DOS DEPUTADOS, 2016).
} 
equivocada de que o cuidado dos filhos é uma obrigação materna exclusiva” (CÂMARA DOS DEPUTADOS, 2016). A metonímia, embora com peso menor, também aparece nas justificativas de todos os projetos mencionados no parágrafo anterior. Ela surge para destacar uma diferença que, a juízo dos parlamentares, faz diferença: o momento de fragilidade pelo qual passa a mãe, seja em razão da gravidez, seja em razão da recuperação pós-parto. Longe de produzir desigualdade, a diferença é constitucionalmente amparada. Aqui, a diferença é estrategicamente utilizada como justificativa para o afastamento momentâneo do pai do trabalho remunerado.

Todos os projetos examinados promovem a responsabilidade do pai para além daquele aspecto tradicionalmente associado à paternidade, o provimento material da família. Para tanto, num primeiro momento, negam a paternidade tradicional. Uma vez negada a paternidade tradicional, recorrem à metáfora e à metonímia, notadamente à metáfora, para reinventar a paternidade. Aqui, negação, metáfora e metonímia se intermesclam no repúdio do status quo. A reinvenção da paternidade emerge como parte integrante de um projeto mais amplo de interrupção das dissimetrias de gênero postas em movimento pelo Estado. Se, pela negação, a paternidade tradicional é recalcada, dando lugar a um vazio que demanda preenchimento, é pela interação entre metáfora e metonímia, é dizer, é pela tensão entre identidade e diferença que se reconstroem concepções da paternidade, a igualdade de gênero e, em última instância, a identidade constitucional. Enquanto a identidade revela vínculos de afeto, comuns não só às mães, mas também aos pais, a diferença, a seu passo, desvela a fragilidade momentânea da mãe ou a divisão sexual do trabalho. São estes alguns dos elementos constitutivos da concepção da paternidade que ali se fabrica. Forjam-se imagens mais inclusivas ou mais democráticas da identidade e do sujeito constitucionais.

Imagens mais inclusivas, mas não menos contraditórias. Algumas das propostas legislativas, pareceres e votos em separado recorrem, como vimos, a argumentos metafóricos numa censura ao atual período de gozo do direito à licença-paternidade. Argumentam que o aumento proposto, seja ele de quinze, trinta ou noventa dias, embora "longe do ideal”, representa um incremento da igualdade de gênero, precisamente porque, com a prorrogação, o pai poderá “auxiliar” ou “apoiar” a mãe no cuidado das(os) filhas(os). Enquanto discursos constitucionais situados, revelam tensões e contradições imanentes às práticas maternas e paternas cotidianas. Diferentemente do Projeto de Lei do Senado $n^{\circ} 652 / 2015^{30}$, que fixa a licença-paternidade em 120 dias e é expressamente justificado, entre outros aspectos, pela “consolidação dos casamentos homoafetivos” (SENADO FEDERAL,

\footnotetext{
${ }^{30}$ O Projeto de Lei do Senado no 879/2011, da Senadora Vanessa Grazziotin (PCdoB/AM), “[a]crescenta dispositivos à Consolidação das Leis do Trabalho, aprovada pelo Decreto-Lei $n^{\circ} 5.452$, de $1^{\circ}$ de maio de 1943 , e à Lei $n^{\circ} 8.213$, de 24 de julho de 1991, para dispor sobre a licença-paternidade” (SENADO FEDERAL, 2015).
} 
2015), para a maioria das proposições aqui analisadas, a paternidade surge muitas vezes relegada à sombra do protagonismo materno.

Há uma identificação mais ou menos explícita da paternidade com a família nuclear heterossexual, como se se tratasse de níveis distintos de responsabilidade - a responsabilidade da mãe, mais absorvente, e a responsabilidade do pai, mais apagada. Como se a igualdade de gênero não reclamasse antes a redivisão radical dos encargos domésticos e de cuidado das crianças do que a mera “ajuda” ou “apoio” paterno. Como se as paternidades, ainda que mais elásticas, se circunscrevessem aos arranjos familiares heterossexuais normalizados e normalizadores. É dizer, as revisões da paternidade afirmam um modelo familiar específico, o modelo nuclear, monogâmico, heteronormativo. Não por outra razão, muitas vezes se justifica a ampliação do direito fundamental à licença-paternidade, como o faz a Proposta de Emenda à Constituição no 41/2015 ${ }^{31}$, como medida de “proteção à maternidade, à gestante, à infância [...] à família [...] e à criança” (SENADO FEDERAL, 2015b), mas não ao pai, não à paternidade, aqui instrumentalizados.

Essas estratégias discursivas produzem novas hierarquias internas ${ }^{32} \mathrm{e}, \mathrm{com}$ isso, limitam os potenciais emancipatórios das paternidades enquanto possíveis modos de ser, uns entre tantos outros, das masculinidades. Não só estar atento a esses movimentos que delimitam sujeitos e possibilidades - mais especificamente, que naturalizam paternidades heterossexuais -, mas também perturbá-los significa levar a sério a perspectiva crítica de que fala Butler (2003, p. 230), “a única que se pode reivindicar enquanto auto-reflexiva e não-dogmática”, sob pena de se “circunscrever a realidade de maneira perigosa” (2003, p. 260). A própria possibilidade de desestabilizar o mito da maternidade e de explorar e nomear experiências que transbordam as representações correntes do pai provedor, do pai autoridade, do pai modelo ou pai herói, como sugere Figueroa Perea (2014), depende desta perspectiva crítica. O que está em jogo, em última análise, é a possibilidade de subversão dos “dividendos patriarcais”, de reconfiguração das engrenagens da divisão sexual do trabalho, é dizer, de densificação da igualdade constitucional.

\footnotetext{
${ }^{31}$ A PEC 41/2015, apresentada pelo Senador Alvaro Dias (PV/PR), “[a]ltera a Constituição para ampliar a duração da licença-maternidade e da licença-paternidade” (SENADO FEDERAL, 2015b).

${ }^{32}$ As tensões mencionadas também aparecem na fala da Presidenta Dilma Rousseff, quando do anúncio da ampliação da licença-paternidade para servidores regidos pela Lei $n^{0}$ 8.112/1990. Em defesa do compromisso mútuo, de mães e pais, com o cuidado direto da prole, declarou Dilma Rousseff: “estamos propondo a ampliação da licença-paternidade para os funcionários públicos, em vez de cinco, [vão] gozar de 20 dias. Estamos incentivando os homens funcionários públicos desse País a ajudar as mulheres”.
} 


\section{REFERÊNCIAS}

AGUAYO, Francisco; BARKER, Gary; KIMELMAN, Eduardo. Editorial. Paternidad y Cuidado em América Latina: Ausencias, Presencias y Transformaciones. Masculinities and Social Change, v. 5, n. 2, p. 98-107, junho 2016.

ARAÚJO, Clara; SCALON, Celi. Gênero, família e trabalho no Brasil. Rio de Janeiro: Editora FGV, 2005.

BADINTER, Elisabeth. O conflito: a mulher e a mãe. Tradução Véra Lucia dos Reis. Rio de Janeiro: Record, 2011.

BADINTER, Elisabeth. Um amor conquistado: o mito do amor materno. Tradução Waltensir Dutra. Rio de Janeiro: Nova Fronteira, 1985.

BADINTER, Elisabeth. XY: Sobre a Identidade Masculina. Tradução Maria Ignez Duque Estrada. Rio de Janeiro: Nova Fronteira, 1993.

BEAUVOIR, Simone de. A mulher desiludida. Tradução Helena Silveira e Maryan A. Bon Barbosa. Rio de Janeiro: Nova Fronteira, 2015.

BRASIL. Ata da 209ª sessão da Assembleia Nacional Constituinte em 25 de fevereiro de 1988. Diário da Assembleia Nacional Constituinte, Brasília, nº 191, p. 7.627-7.678, 25 fev. 1988.

BRASIL. Constituição da República Federativa do Brasil. Brasília: Senado Federal, 2016.

BRUM, Eliane. A “safada” que “abandonou” seu bebê, El País, 2015.

BUTLER, Judith. O parentesco é sempre tido como heterossexual? Cad. Pagu, n. 21, p. 19-260, 2003.

CÂMARA DOS DEPUTADOS. Parecer do Deputado Júlio Delgado (PSB/MG) na Comissão de Trabalho, de Administração e Serviço Público referente ao Projeto de Lei n. 3935/2008 e apensos. 2013a. Texto original. Câmara dos Deputados. Disponível em: <https://goo.gl/pQfocr>. Acesso em: 25 jun. 2016.

CÂMARA DOS DEPUTADOS. Parecer do Deputado Silvio Costa (PTB/PE) na Comissão de Trabalho, de Administração e Serviço Público referente ao Projeto de Lei n. 3935/2008 e apensos. Texto original. Câmara dos Deputados. 2012a. Disponível em: <https://goo.gl/3G5DMP>. Acesso em: 25 jun. 2016.

CÂMARA DOS DEPUTADOS. Projeto de Lei n. 1131/2015. Altera dispositivos da Consolidação das Leis do Trabalho, aprovada pelo Decreto-Lei $N^{0} 5.452$, de $1^{\circ}$ de maio de 1943 , para ampliar a licença paternidade para trinta dias. Texto original. Câmara dos Deputados. 2015. Disponível em: <https://goo.gl/ypjqUX>. Acesso em: 25 jun. 2016.

CÂMARA DOS DEPUTADOS. Projeto de Lei n. 3325/2012. Regulamenta a Licença Paternidade a que se refere o artigo $7^{\circ}$, inciso XIX, da Constituição Federal. Câmara dos Deputados. 2012b. Disponível em: <https://goo.gl/wzkLX1>. Acesso em: 25 jun. 2016. Texto Original. 
CÂMARA DOS DEPUTADOS. Projeto de Lei n. 3935/2008. Acrescenta arts. 473-A a 473-C à Consolidação das Leis do Trabalho - CLT, aprovada pelo Decreto-Lei $n^{\circ} 5.452$, de $1^{\circ}$ de maio de 1943, para regulamentar a licença-paternidade a que se refere o inciso XIX do art. $7^{\circ}$ da Constituição Federal. Texto original. Câmara dos Deputados. 2008. Disponível em: <https://goo.gl/Lau3eD>. Acesso em: 25 jun. 2016.

CÂMARA DOS DEPUTADOS. Projeto de Lei n. 4878/2016. Altera a redação do Inciso III, do art. 473 da Consolidação das Leis do Trabalho, aprovada pelo Decreto-lei n. ${ }^{\circ}$ 5452, de $1^{\circ}$ de maio de 1943, e o artigo 208, da Lei $\mathrm{n}^{\circ}$. 8.112, de 11 de dezembro de 1990 para definir a duração da licença paternidade. Texto original. Câmara dos Deputados. 2016. Disponível em: <https://goo.gl/c1NYoF>. Acesso em: 25 jun. 2016.

CÂMARA DOS DEPUTADOS. Projeto de Lei n. 879/2011. Acrescenta art. 473-A ao Decreto-Lei $\mathrm{n}^{\circ} 5.452$, de $1^{\circ}$ de maio de 1943, que aprova a Consolidação das Leis do Trabalho, para estipular em 30 (trinta) dias a licença-paternidade. Texto original. Câmara dos Deputados. 2011. Disponível em: <https://goo.gl/ZYNs8U>. Acesso em: 25 jun. 2016.

CÂMARA DOS DEPUTADOS. Voto em Separado do Deputado Assis Melo (PCdoB/RS) na Comissão de Trabalho, de Administração e Serviço Público referente ao Projeto de Lei n. 3935/2008 e apensos. Texto original. Câmara dos Deputados. 2013b. Disponível em: <https://goo.gl/ACvdBi>. Acesso em: 25 jun. 2016.

CÂMARA DOS DEPUTADOS. Voto em Separado do Deputado Eudes Xavier (PT/CE) na Comissão de Trabalho, de Administração e Serviço Público referente ao Projeto de Lei n. 3935/2008 e apensos. Texto original. Câmara dos Deputados. 2013c. Disponível em: <https://goo.gl/WJyTwZ>. Acesso em: 25 jun. 2016.

CARVALHO NETTO, Menelick de. A contribuição do direito administrativo enfocado da ótica do administrado para uma reflexão acerca dos fundamentos do controle de constitucionalidade das leis no Brasil: um pequeno exercício de Teoria da Constituição. Revista do TST, Brasília, v. 68, n. 2, p. 67-84. abr/jun. 2002.

CARVALHO NETTO, Menelick de. A hermenêutica constitucional e os desafios postos aos direitos fundamentais. In: SAMPAIO, José Adércio Leite (Coord.). Jurisdição constitucional e direitos fundamentais. Belo Horizonte: Del Rey, 2003a, p. 141-163.

CARVALHO NETTO, Menelick de. Racionalização do ordenamento jurídico e democracia. Assembleia Legislativa de Minas Gerais. A Consolidação das leis e o aperfeiçoamento da democracia. Belo Horizonte, p. 13-38, 2003b.

CATTONi DE OLIVEIRA, Marcelo Andrade. A Democracia Constitucional no Estado Democrático de Direito. 2016a. Disponível em: <https://goo.gl/iUFVaL>. Acesso em: 19 maio 2016.

CATTONI DE OLIVEIRA, Marcelo Andrade. Democracia constitucional: um paradoxo? Um diálogo, ainda que breve, com Luhmann, Habermas e Derrida. 2016b. Disponível em: $<$ https://goo.gl/pkJpTP>. Acesso em: 19 maio 2016. 
CATTONI DE OLIVEIRA, Marcelo Andrade. Notas programáticas para uma nova história do processo de constitucionalização brasileiro. In: CATTONI DE OLIVEIRA, Marcelo Andrade (Coord.). Constitucionalismo e História do Direito. Belo Horizonte: Pergamum, 2011. p. 19-59.

CATTONi DE OLIVEIRA, Marcelo Andrade. Poder Constituinte e Patriotismo Constitucional: O projeto constituinte do Estado Democrático de Direito na Teoria Discursiva de Jürgen Habermas. Belo Horizonte: Mandamentos, 2006.

CATTONI DE OLIVEIRA, Marcelo Andrade. Qual o sentido do Projeto Constituinte do Estado Democrático de Direito? Um exercício de Patriotismo Constitucional no marco da Teoria do Discurso, de Jürgen Habermas. 2016c. Disponível em: <https://goo.gl/9PYjBz>. Acesso em: 13 maio 2016.

CATTONI DE OLIVEIRA, Marcelo Andrade; MARQUES, Stanley Souza. Direito à licençapaternidade e masculinidades no Estado Democrático de Direito. Revista Culturas Jurídicas, São Paulo, v. 4, n. 9, p. 222-248, 2017.

CONNELL, R. W. Masculinities. Berkeley: University of California Press, 2005.

CONNELL, R. W. Políticas da masculinidade. Educação \& Realidade, n. 20, v.2, p. 185-206, 1995.

CONNELL, Raewyn; PEARSE, Rebecca. Gênero: uma perspectiva global. Tradução e revisão técnica Marília Moschkovich. São Paulo: nVersos, 2015.

COSTA, Jurandir Freire. Ordem médica e norma familiar. Rio de Janeiro: Edições Graal, 2004.

FIGUEROA-PEREA, Juan Guillermo. Algunas propuestas dialógicas para relacionar paternidad, salud y mortalidad. Iztapalapa. Revista de Ciencias Sociales y Humanidades, n. 77, p. 55-75, julhodezembro 2014.

FORNA, Aminatta. Mãe de todos os mitos: como a sociedade modela e reprime as mães. Tradução Angela Lobo de Andrade. Rio de Janeiro: Ediouro, 1999.

GILMORE, David D. Hacerse hombre. Concepciones culturales de la masculinidad. Traducción Patrik Ducher. Barcelona: Paidós, 1994.

HAYS, Sharon. As contradições culturais da maternidade. Tradução Beatriz Sidou. Rio de Janeiro: Gryphus, 1998.

HIRATA, Helena; KERGOAT, Danièle. A divisão sexual do trabalho revisitada. In: MARUANI, Margaret; HIRATA, Helena (Org.). As novas fronteiras da desigualdade: homens e mulheres no mercado de trabalho. Tradução Clevi Rapkievicz. São Paulo: Editora Senac São Paulo, 2003.

HIRATA, Helena; KERGOAT, Danièle. Novas configurações da divisão sexual do trabalho. Caderno de Pesquisa, São Paulo, v. 37, n.132, p. 595-609, set./dez. 2007.

KIMMEL, MICHAEL S. Homofobia, temor, vergüenza y silencio en la identidade masculina. In: VALDÉS, Teresa; OLAVARRÍA, José (Ed.). Masculinidad/es: poder y crisis. Santiago: Isis Internacional, 1997. p. 49-62. 
LEVTOV R. et al. State of the World's Fathers: A MenCare Advocacy Publication. Washington, DC: Promundo, Rutgers, Save the Children, Sonke Gender Justice, and the MenEngage Alliance, 2015.

MARQUES, Stanley Souza. A Identidade do Sujeito Constitucional e o Direito Fundamental à Licença-paternidade: da paternidade tradicional às paternidades constitucionais. 2016a. Dissertação (Mestrado em Direito) - Universidade Federal de Minas Gerais, Belo Horizonte, 2016.

MARQUES, Stanley Souza. Ampliar a licença-paternidade para despatriarcalizar o Estado e a sociedade. Gênero e Direito, Paraíba, n. 1, p. 241-260, 2015.

MARQUES, Stanley Souza. Identidade e Diferença: Licença-paternidade no Brasil e a Reconstrução da Identidade do Sujeito Constitucional. In: FREITAS, Riva Sobrado de; SANTIAGO, Mariana Ribeiro; XIMENES, Julia Maurmann (Org.). Direitos Fundamentais e Democracia IV. Florianópolis: CONPEDI/UFSC, p. 343-366, 2014.

MARQUES, Stanley Souza. Uma reconstrução constitucional-democrática das paternidades. Empório do Direito, 2016b.

MARTINS, Ana Paula Vosne. História da maternidade no Brasil: arquivos, fontes e possibilidades de análise. ANPUH - XXIII Simpósio Nacional de História. Londrina: ANPUH, 2005.

MATOS, Ana Carla Harmatiuk; OLIVEIRA, Ligia Ziggiotti de; NATIVIDADE, João Pedro Kostin Felipe de. Licença parental como agenda para a igualdade de gênero: diálogos entre modelos sueco e brasileiro. Revista da Faculdade de Direito da UFPR, Curitiba, vol. 61, n. 3, set./dez. 2016, p. 345363.

MATOS, Marlise. Democracia, sistema político brasileiro a exclusão das mulheres: a urgência em se aprofundar estratégias de descolonização e despatriarcalização do Estado. Revista do Observatório Brasil de Igualdade de Gênero, Brasília, n. 7, p. 24-37, dezembro, 2015.

NASCIMENTO, Carla. Pai é 'convidado a se retirar' de fraldário enquanto cuidava de bebê e mãe critica: ‘Retrocesso’. Extra, 2016.

OIT. Mulheres no trabalho. Tendências 2016. Genebra: OIT, 2016.

PITANGUY, Jacqueline. Mulheres, Constituinte e Constituição. In: ABREU, Maria Aparecida (Org.). Redistribuição, reconhecimento e representação: diálogos sobre igualdade de gênero. Brasília: IPEA, 2011.

RAGO. Margareth. Do cabaré ao lar: a utopia da cidade disciplinar e a resistência anarquista. Brasil 1890-1930. São Paulo: Paz e Terra, 2014.

ROSENFELD, Michel. A identidade do sujeito constitucional. Tradução Menelick de Carvalho Netto. Belo Horizonte: Mandamentos, 2003a.

ROSENFELD, Michel. Hacia una reconstrucción de la igualdad constitucional. In: CARBONELL, Miguel (Org.). El principio constitucional de la igualdad. México: Comisión Nacional de los Derechos Humanos, 2003b. p. 411-443. 
ROSENFELD, Michel. The Constitutional Subject, its Other, and the Perplexing Quest for an Identity of its Own: A Reply to My Critics. Cardozo Law Review, v.33, n.5, p. 1.937-1.970, jun. 2012.

ROSENFELD, Michel. The Identity of the Constitutional Subject: Selfhood, Citizenship, Culture, and Community. London and New York: Routledge, 2010.

SALCEDO REPOLÊS, Maria Fernanda. A construção da identidade do sujeito constitucional em teorias hermenêuticas representativas dos paradigmas de Estado e de Direito modernos. Revista Direito Izabela Hendrix, v. 3, n. 3, p. 153-166, 2004.

SENADO FEDERAL. Projeto de Lei do Senado n. 652/2015. Acrescenta dispositivos à Consolidação das Leis do Trabalho, aprovada pelo Decreto-Lei $n^{\circ} 5.452$, de $1^{\circ}$ de maio de 1943 , e à Lei $\mathrm{n}^{0}$ 8.213, de 24 de julho de 1991, para dispor sobre a licença-paternidade. Texto original. Senado Federal. 2015. Disponível em: <https://goo.gl/qbRNB1>. Acesso em: 25 jun. 2016.

SENADO FEDERAL. Projeto de Lei do Senado n. 666/2007. Regulamenta a licença-paternidade a que se refere o inciso XIX, do art. $7^{\circ}$, da Constituição Federal. Texto original. Senado Federal. 2007. Disponível em: <https://goo.gl/ZYNs8U>. Acesso em: 25 jun. 2016.

Marcelo Andrade Cattoni de Oliveira Professor Titular de Direito Constitucional e Subcoordenador do Programa de PósGraduação em Direito da Faculdade de Direito da UFMG. Bolsista de Produtividade do CNPq (1D). Mestre e Doutor em Direito (UFMG). Pós-Doutorado em Teoria do Direito (Roma TRE).E-mail: mcattoni@gmail.com

Stanley Souza Marques Doutorando, com bolsa CAPES, e Mestre em Direito pela Universidade Federal de Minas Gerais (UFMG).E-mail: marques.stanley@gmail.com 